ISSN 1678-3921

Journal homepage: www.embrapa.br/pab

For manuscript submission and journal contents, access: www.scielo.br/pab
Fabíola Vieira Gonçalves ${ }^{(1 凶)}$ (iD, Leonardo Oliveira Medici(2) (iD, Marcos Paulo Santos da Fonseca ${ }^{(1)}$ (D), Salete Aparecida Gaziola(3) (iD), Gepatrik Rodrigues Lima ${ }^{(1)}$ (iD, David Cabral Macedo(1) (D) and Ricardo Antunes Azevedo (3) (ID

(1) Universidade Federal Rural do Rio de Janeiro, Departamento de Fitotecnia, BR 465, Km 07, CEP 23890-000 Seropédica, RJ, Brazil.

E-mail: fabiolaufrri@gmail.com, marquimmica.ufrrj@yahoo.com.br, gepatrik@outlook.com,

davidmacedo.rj@gmail.com

(2) Universidade Federal Rural do Rio de Janeiro, Departamento de Ciências Fisiológicas, BR 465, Km 07, CEP 23890-000 Seropédica, RJ, Brazil. E-mail: Imedici@gmail.com

(3) Universidade de São Paulo, Escola Superior de Agricultura Luiz de Queiroz, Departamento de Genética, Avenida Pádua Dias, o 11, CEP 13418-900 Piracicaba, SP, Brazil.

E-mail: sagaziol@usp.br, raa@usp.br

$\bowtie$ Corresponding author

Received

June 5, 2018

Accepted

April 20, 2020

How to cite

GONÇALVES, F.V.; MEDICI, L.O.

FONSECA, M.P.S. da; GAZIOLA, S.A.; LIMA,

G.R.; MACEDO, D.C.; AZEVEDO, R.A.

Characterization of the development of cowpea cultivars and of the quantity and quality of

proteins in their grains. Pesquisa Agropecuária Brasileira, v.55, e00837, 2020. DOI: https://doi. org/10.1590/S1678-3921.pab2020.v55.00837.

\section{Characterization of the development of cowpea cultivars and of the quantity and quality of proteins in their grains}

\begin{abstract}
The objective of this work was to evaluate cowpea (Vigna unguiculata) cultivars regarding plant development and the quantity and quality of soluble proteins in their grains, for breeding purposes. The experiment was conducted in a greenhouse, in a completely randomized experimental design, with the Paulistinha, BRS Novaera, Epace 10, and BR 17-Gurguéia cultivars. Leaf area, shoot fresh and dry matter, leaf protein content, number of nodules, and nodule and root dry matter were evaluated. In mature grains, soluble fractions and soluble amino acids were also quantified, and the electrophoretic analysis was performed with protein denaturation. There were no differences between cultivars for the plant development variables. However, protein quantity and quality in the grain differed between cultivars. 'BRS Novaera' and 'BR 17-Gurguéia' showed a higher soluble protein content in their grains. 'BRS Novaera' exhibited higher contents of two soluble sulfur amino acids methionine and cysteine - , not differing from 'BR 17-Gurguéia' regarding methionine content. Both cultivars presented protein band polymorphism, but BRS Novaera had an extra band for albumins. The BRS Novaera and BR 17-Gurguéia cultivars have the highest content of soluble proteins in their grains and the greatest protein polymorphism, which makes them suitable for improving the nutritional quality of cowpea.
\end{abstract}

Index terms: Vigna unguiculata, amino acids, grain protein, SDS-PAGE.

\section{Caracterização do desenvolvimento de cultivares de feijão-caupi e do conteúdo e da qualidade proteica dos seus grãos}

Resumo - O objetivo deste trabalho foi avaliar cultivares de feijão-caupi (Vigna unguiculata) quanto ao desenvolvimento da planta e à quantidade e à qualidade de proteínas solúveis em seus grãos, com vistas ao melhoramento. O experimento foi conduzido em casa de vegetação, em delineamento experimental inteiramente casualizado, com as cultivares Paulistinha, BRS Novaera, Epace 10 e BR 17-Gurguéia. Avaliaram-se área foliar, peso fresco e seco da parte aérea, conteúdo de proteína foliar, número de nódulos, e massa seca de nódulos e de raiz. Nos grãos maduros, também quantificaram-se as frações solúveis e os aminoácidos solúveis, e a análise eletroforética foi realizada com desnaturação das proteínas. Não houve diferenças entre as cultivares quanto às variáreis do desenvolvimento da planta. No entanto, a quantidade e a qualidade das proteínas nos grãos diferiram entre as cultivares. 'BRS Novaera' e 'BR 17-Gurguéia' apresentaram maior teor de proteína solúvel nos seus grãos. 'BRS Novaera' apresentou maior teor de dois aminoácidos sulfurados solúveis - metionina e cisteína - , não tendo diferido de 'BR 
17-Gurguéia' quanto ao conteúdo de metionina. Ambas as cultivares apresentaram polimorfismo de bandas, mas BRS Novaera apresentou uma banda extra para albuminas. As cultivares BRS Novaera e BR 17-Gurguéia apresentam o maior conteúdo de proteínas solúveis nos seus grãos e o maior polimorfismo de proteínas, o que as torna adequadas para o melhoramento nutricional do feijão-caupi.

Termos para indexação: Vigna unguiculata, amino ácidos, proteína do grão, SDS-PAGE.

\section{Introduction}

Pulses are second in agricultural importance, only behind Gramineae (Singh et al., 2007). They provide a good source of protein, ranging from 18 to $35 \%$, and supplement cereals with protein, minerals, and vitamins of the B complex (Elhardallou et al., 2015). Among the grain legumes, cowpea [Vigna unguiculata (L.) Walp.] is considered an important source of protein, essential minerals $(\mathrm{Ca}, \mathrm{Cu}, \mathrm{Fe}, \mathrm{K}, \mathrm{Mg}, \mathrm{Mn}$, $\mathrm{Na}, \mathrm{P}$, and $\mathrm{Zn}$, for example), vitamins (A, C, B1, B2, B5, B6, and B9), carbohydrates, and antioxidants that are fundamental for human health, growth, and development (Gerrano et al., 2019). In Brazil, the crop is cultivated throughout the entire country, especially in the Northern and Northeastern regions and, more recently, in the Midwest.

The genetic variability among cowpea genotypes for different proteins helps to improve the nutritional quality of the species through genetic breeding (Gerrano et al., 2019). The 'BRS Novaera', 'BR 17-Gurguéia', 'Paulistinha', and 'Epace 10' genotypes, for example, were developed to increase the production potential, resistance to viruses, tolerance to drought, and commercial quality of grains and pods. However, although agronomic data about these genotypes is available, more detailed information on grain nutritional characteristics is still necessary.

Further information on cultivar characterization, including shoot development, nodulation, and leaf soluble protein content, may help in the search for answers regarding nitrogen assimilation and remobilization for the synthesis of grain proteins. Leaf proteins and, in particular, photosynthetic proteins of plastids are extensively degraded during senescence, providing a large source of $\mathrm{N}$ that plants can tap to supplement the nutrition of growing organs such as new leaves and seeds (Masclaux-Daubresse et al., 2008).

Biological $\mathrm{N}$ fixation (BNF) is a key source of $\mathrm{N}$ for cowpea, which is one of the crops with the highest protein content and, therefore, a high demand for the nutrient. Studies carried out with soybean [Glycine $\max ($ L.) Merr.] and common bean (Phaseolus vulgaris L.) have already shown that $\mathrm{N}$ derived from BNF is more easily moved to pods during grain filling than nitrate-N (Santos et al., 2013). In addition, characteristics related to the nodulation process, such as number of nodules, nodule dry matter, and root dry matter, may indicate nodulation efficiency, mainly when evaluated at important phenological stages such as flowering.

Therefore, data on nutritional and physiological parameters is vital to help plant breeders choose high-protein lines (Ravelombola et al., 2016). Due to the great diversity in their protein content, different cowpea cultivars have been characterized in recent studies, aiming for further application in breeding programs with a considerable interest in improving the nutritional quality - in terms of essential amino acids - of high-protein legumes (Gupta et al., 2010).

The objective of this work was to evaluate cowpea cultivars regarding plant development and the quantity and quality of soluble proteins in their grains, for breeding purposes.

\section{Materials and Methods}

The study was carried out in a greenhouse belonging to the Department of Crop Science of Universidade Federal Rural do Rio de Janeiro, located in the state of Rio de Janeiro, Brazil $\left(22^{\circ} 45^{\prime} \mathrm{S}, 43^{\circ} 41^{\prime} \mathrm{W}\right.$, at an altitude of $40 \mathrm{~m}$ ). The predominant climate in the region is Aw according to Köppen-Geiger's classification, with hot and rainy summers and dry winters. Plants were cultivated in 8.0-L pots containing an Argissolo Vermelho-Amarelo, i.e., a Kanhapudalf, with the following chemical characteristics: $2.3 \mathrm{mg} \mathrm{dm}^{-3} \mathrm{P}, 72$ $\mathrm{mg} \mathrm{dm}{ }^{-3} \mathrm{~K}\left(\mathrm{KCl} 1.0 \mathrm{~mol} \mathrm{~L}^{-1}\right), 1.8 \mathrm{cmol}_{\mathrm{c}} \mathrm{dm}^{-3} \mathrm{Ca}^{+2}, 0.8$ $\mathrm{cmol}_{\mathrm{c}} \mathrm{dm}^{-3} \mathrm{Mg}^{+2}$, and $0 \mathrm{cmol}_{\mathrm{c}} \mathrm{dm}^{-3} \mathrm{Al}^{+3}\left(\mathrm{HCl} 0.05 \mathrm{~mol} \mathrm{~L}^{-1}\right.$ $\left.+\mathrm{H}_{2} \mathrm{SO}_{4} 0.0125 \mathrm{~mol} \mathrm{~L}^{-1}\right)$. Fertilization was carried out according to Manual de Calagem e Adubação do Estado do Rio de Janeiro (Freire, 2013), except for N, which was not supplied to the plants, following the usual method of cultivation. Planting was carried out on 
$5 / 16 / 2016$, and the grains were inoculated with Semia 6464 (BR 3262), a specific strain of Bradyrhizobium sp., obtained from the germplasm bank of Embrapa Agrobiologia and currently recommended to supply $\mathrm{N}$ to cowpea. Inoculation was performed as described in Hungria et al. (2003), aiming to allow biological fixation without growth promotion, which is the current practice.

The experimental design was completely randomized, with four treatments (four cultivars) and eight replicates; each experimental plot consisted of two plants. The cowpea cultivars studied were Epace 10, BR 17-Gurguéia, Paulistinha, and BRS Novaera. In order to better characterize the behavior of these genotypes, they were analyzed in four different periods, which were: vegetative growth, from planting to the appearance of the first floral bud; pre flowering, when more than $50 \%$ of the plants had at least one bud at this stage, the root and its nodulation were assessed; full flowering, when at least $50 \%$ of the plants had a fully-expanded flower; pod filling, which begins with the filling of the first pod; and grain storage, when proteins and soluble amino acids were evaluated. The sampling time in days after planting of each cowpea cultivar is detailed in Table 1.

Soluble leaf protein was quantified according to Bradford (1976). The leaf fraction analyzed corresponded to the central leaflet of the third youngest and fully-expanded leaf.

The shoot was separated from the cut roots at the cotyledon insertion point near the stem base, and leaves were separated to measure leaf area using the LI-3000C portable leaf area meter (LI-COR, Lincoln, NE, USA). Nodules were separated from roots, counted, and dried at $60^{\circ} \mathrm{C}$ for 72 hours, and then used to evaluate the potential of BNF. The number of nodules was used to indirectly reveal the relationship between fixation potential and quantitative characteristics (Ferreira et al., 2011).

The grains were harvested at physiological maturation. For the extraction of storage proteins, dried grains were lyophilized and ground, following the method described by Vasconcelos et al. (2010) with some adaptations. Samples of $100 \mathrm{mg}$ each, in three replicates, were taken from a single sample of flour from the grains of different plants. The samples were treated with $1.0 \mathrm{~mL}$ hexane, at room temperature, for $15 \mathrm{~min}$, slightly shaken, centrifuged at $12.000 \mathrm{~g}$ for $5 \mathrm{~min}$, and allowed to dry overnight. The extraction process was sequential, allowing the precipitate from the previous extraction to be used as a pellet for the next extraction. The extraction of the sequential protein fraction included: three globulin extractions with $1.0 \mathrm{~mL}$ $\mathrm{NaCl}\left(0.5 \mathrm{~mol} \mathrm{~L}^{-1}\right)$; three albumin extractions with $1.0 \mathrm{~mL}$ distilled water, with the first extraction being discarded; one prolamin extraction with $0.5 \mathrm{~mL}$ ethanol (70\%); and two glutelin extractions, i.e., acidic glutelin extracted with $1.0 \mathrm{~mL} \mathrm{HCl}\left(0.1 \mathrm{~mol} \mathrm{~L}^{-1}\right)$ and basic glutelin extracted with $1.0 \mathrm{~mL} \mathrm{NaOH}\left(0.1 \mathrm{~mol} \mathrm{~L}^{-1}\right)$, in this order.

The centrifugations for the extraction of prolamins and glutelins were performed at $25^{\circ} \mathrm{C}$, i.e., at room temperature, while the extractions of albumins and globulins were carried out at $4^{\circ} \mathrm{C}$. The protein supernatant was retrieved after centrifugation, and, when two centrifugations were performed, both supernatants were combined and stored at $-80^{\circ} \mathrm{C}$.

The protein fraction content of albumins, globulins, prolamins, and acid glutelins were determined according to Bradford (1976), whereas, the method used for basic glutelin was similar to that of Lowry et al. (1951). All samples were quantified using the Protein Assay and DC Protein Assay kits (Bio-Rad Laboratories, Inc., Hercules, CA, USA), and bovine

Table 1. Sampling time in days after planting (DAP) of the four cowpea (Vigna unguiculata) cultivars in four different periods.

\begin{tabular}{lcccc}
\hline Cultivar & \multicolumn{4}{c}{ Sampling time in days after planting } \\
\cline { 2 - 5 } & Vegetative growth & Pre flowering & Full flowering & Pod filling \\
\hline BRS Novaera & 21 & 49 & 52 & 60 \\
BR 17-Gurguéia & 21 & 49 & 60 & 68 \\
Paulistinha & 21 & 49 & 60 & 68 \\
Epace 10 & 21 & 49 & 60 & 68 \\
\hline
\end{tabular}


albumin serum was used as a standard. The values were obtained in relation to a standard curve by linear regression. The total percentage of the soluble protein was based on the sum of the protein fractions.

The electrophoretic analysis was carried out under denaturing conditions of $0.1 \%(\mathrm{w} / \mathrm{v})$ sodium dodecyl sulfate in $13 \%$ polyacrylamide gel, with known concentrations of protein loaded onto each lane for each storage protein fraction. The general running conditions were determined at a constant current of $15 \mathrm{~mA}$ per gel. Molecular mass markers were applied to each gel to determine the molecular mass of the proteins, and the gels were prepared and stained with a solution of silver nitrate according to Morrissey (1981).

Soluble amino acid extraction was performed as in Bieleski \& Turner (1966). A 1.0-g sample of lyophilized flour was mixed into a $10-\mathrm{mL}$ solution of methanol, chloroform, and water, in the 12:5:3 ratio, and was incubated overnight at $4^{\circ} \mathrm{C}$. The samples were centrifuged at $10.000 \mathrm{~g}$ for $20 \mathrm{~min}$, at $4^{\circ} \mathrm{C}$, to remove cell debris, and the supernatant was collected and mixed with $1.0 \mathrm{~mL}$ chloroform and $1.5 \mathrm{~mL}$ ultrapure water. The two layers formed were separated by centrifugation at $10.000 \mathrm{~g}$ for $20 \mathrm{~min}$ at $4^{\circ} \mathrm{C}$. The aqueous stage was carefully removed and incubated at $38^{\circ} \mathrm{C}$ in a water bath for 1 hour and then lyophilized. The pellet was resuspended in $1.0 \mathrm{~mL}$ distilleddeionized water, and the solution of soluble amino acids was frozen at $-20^{\circ} \mathrm{C}$ before the separation and quantification of the amino acids.

Lyophilized samples were reconstituted in ultrapure water. A volume of $10 \mu \mathrm{L}$ was derivatized according to the manufacturer's recommendations in $70 \mu \mathrm{L}$ borate buffer and $20 \mu \mathrm{L}$ of the AccQ-fluor derivative agent (Waters Corporation, Milford, MA, USA). The mixture was heated to $55^{\circ} \mathrm{C}$ for $10 \mathrm{~min}$ and, after it cooled down, $1.0 \mu \mathrm{L}$ of each sample was used for separation and quantification through the Acquity UPLC system (Waters Corporation, Milford, MA, USA). In the UPLC system, the reverse phase separation was performed with the $\mathrm{BEH} \mathrm{C} 18$ column $(100 \mathrm{~mm} \times 2.1 \mathrm{~mm}$ i.d., $1.7 \mu \mathrm{m})$ at $46^{\circ} \mathrm{C}$, with a flow rate of $0.7 \mathrm{~mL}$ per min between the following eluents: AccQ-Tag Waters, 10\% acetonitrile, 100\% Milli-Q water, and $100 \%$ acetonitrile. The derivatized product was detected at $260 \mathrm{~nm}$. The amino acids histidine, serine, arginine, glycine, aspartate, threonine, alanine, proline, cysteine, lysine, tyrosine, methionine, valine, isoleucine, leucine, and phenylalanine were determined based on the amino acid standard $\mathrm{H}$, product number NCI0180 (Thermo Fisher Scientific, Waltham, MA, USA).

Statistical differences in the quantitative characteristics among genotypes were compared by the LSD test, at 5\% probability, using the Sisvar software (Universidade Federal de Lavras, Lavras, MG, Brazil).

\section{Results and Discussion}

The BRS Novaera cultivar showed the highest values for shoot fresh and dry matter and leaf area at the vegetative growth stage (Table 2). The leaf protein content was significantly higher in the Paulistinha cultivar, compared with BRS Novaera and BR 17-Gurguéia.

At pre flowering, cultivars differed regarding leaf protein and root dry matter (Table 3). 'BRS Novaera' and 'Epace 10' exhibited the lowest and highest leaf protein contents, respectively, while 'Paulistinha' had a greater root dry matter. The variables number of nodules and nodule dry matter did not differ significantly among cultivars, varying from 127 to 182 and from 0.36 to 0.49 , respectively (Table 3 ). Since the number of nodules was close to that reported in the literature, all cultivars received an adequate supply of $\mathrm{N}$ by FBN, similarly to what was observed by Ferreira et al. (2011). Silva et al. (2012), for example, studying the application of different inoculum rates in the BRS Pujante cowpea cultivar, found a greater accumulation of $\mathrm{N}$ in the shoot of inoculated plants than in that of those fertilized with $\mathrm{N}$, besides less than 80 nodules per plant.

At full flowering, when $50 \%$ of the plants had the first fully-open flower, significant differences were observed for shoot fresh and dry matter and leaf protein (Table 2). At this stage, the BR 17-Gurguéia cultivar showed the highest values for shoot dry matter and leaf protein.

In general, leaf protein content increased until the pre-flowering stage, decreasing afterwards. This behavior was evident mainly for the BR 17-Gurguéia cultivar (Table 2), which, at full flowering, presented a leaf protein content considerably higher than that of the other cultivars; however, at the stage of pod filling, the cultivars did not differ regarding this characteristic. The observed decrease in protein content may be

Pesq. agropec. bras., Brasília, v.55, e00837, 2020

DOI: 10.1590/S1678-3921.pab2020.v55.00837 
associated with leaf protein mobilization in function of the soluble protein content in the grains, since 'BR 17-Gurguéia' showed a high total soluble protein. Therefore, grain protein content was inversely proportional to leaf protein content; for instance, the Epace 10 cultivar, which remained with a higher leaf protein content until the pod-filling stage, also showed a lower grain soluble protein content than BR 17-Gurguéia. According to Peoples et al. (1983), each fruit absorbs $\mathrm{N}$ from all available sources, but leaf $\mathrm{N}$ is preferentially distributed to nearby fruits as the lower fruits monopolize the $\mathrm{N}$ exported from the nodulated

Table 2. Averages of leaf area, shoot fresh matter (SFM), shoot dry matter (SDM), and leaf protein content of four cowpea (Vigna unguiculata) cultivars at four phenological stages ${ }^{(1)}$.

\begin{tabular}{|c|c|c|c|c|}
\hline Cultivar & $\begin{array}{c}\text { Leaf area } \\
\left(\mathrm{cm}^{2}\right)\end{array}$ & $\begin{array}{l}\text { SFM } \\
(\mathrm{g})\end{array}$ & $\begin{array}{c}\text { SDM } \\
(\mathrm{g})\end{array}$ & $\begin{array}{c}\text { Protein } \\
\left(\mathrm{mg} \mathrm{BSA} \mathrm{g}{ }^{-1} \mathrm{FM}\right)^{(2)}\end{array}$ \\
\hline & \multicolumn{4}{|c|}{ Vegetative growth } \\
\hline BRS Novaera & $364.5 \mathrm{a}$ & $14.15 \mathrm{a}$ & $1.27 \mathrm{a}$ & $2.23 b$ \\
\hline BR 17-Gurguéia & $263.6 \mathrm{ab}$ & $8.74 b$ & $0.83 b$ & $2.33 b$ \\
\hline Paulistinha & $254.7 b$ & $8.95 b$ & $0.87 \mathrm{~b}$ & $2.58 \mathrm{a}$ \\
\hline Epace 10 & $289.4 \mathrm{ab}$ & $10.22 \mathrm{ab}$ & $0.95 \mathrm{ab}$ & $2.34 \mathrm{ab}$ \\
\hline \multirow[t]{2}{*}{ CV (\%) } & 18.91 & 20.88 & 18.98 & 8.64 \\
\hline & \multicolumn{4}{|c|}{ Pre flowering } \\
\hline BRS Novaera & $1,040.6 \mathrm{a}$ & $46.645 \mathrm{a}$ & $8.52 \mathrm{a}$ & $3.40 \mathrm{~b}$ \\
\hline BR 17-Gurguéia & $1,099.9 \mathrm{a}$ & $42.990 \mathrm{a}$ & $6.99 \mathrm{a}$ & $3.65 b$ \\
\hline Paulistinha & $1,199.9 \mathrm{a}$ & $44.752 \mathrm{a}$ & $7.37 \mathrm{a}$ & $3.52 \mathrm{ab}$ \\
\hline Epace 10 & $1,027.1 \mathrm{a}$ & $42.133 a$ & $6.48 \mathrm{a}$ & $3.67 \mathrm{a}$ \\
\hline \multirow[t]{2}{*}{ CV (\%) } & 17.54 & 18.49 & 21.62 & 5.68 \\
\hline & \multicolumn{4}{|c|}{ Full flowering } \\
\hline BRS Novaera & $1264.3 \mathrm{a}$ & $47.44 b$ & $10.39 b$ & $3.00 \mathrm{~b}$ \\
\hline BR 17-Gurguéia & $1638.7 \mathrm{a}$ & $75.01 \mathrm{a}$ & $16.10 \mathrm{a}$ & $3.85 \mathrm{a}$ \\
\hline Paulistinha & $1237.3 \mathrm{a}$ & $53.28 \mathrm{~b}$ & $9.31 \mathrm{~b}$ & $2.99 \mathrm{~b}$ \\
\hline Epace 10 & $1413.5 \mathrm{a}$ & $61.33 \mathrm{ab}$ & $11.10 \mathrm{~b}$ & $2.96 \mathrm{~b}$ \\
\hline \multirow[t]{2}{*}{ CV (\%) } & 16.44 & 6.46 & 19.5 & 5.39 \\
\hline & \multicolumn{4}{|c|}{ Pod filling } \\
\hline BRS Novaera & $1173.3 \mathrm{a}$ & $84.05 \mathrm{a}$ & $16.43 \mathrm{a}$ & $2.49 \mathrm{ab}$ \\
\hline BR 17-Gurguéia & $1286.9 \mathrm{a}$ & $81.03 \mathrm{a}$ & $16.73 \mathrm{a}$ & $2.67 \mathrm{ab}$ \\
\hline Paulistinha & $1329.7 \mathrm{a}$ & $68.16 \mathrm{a}$ & $13.49 \mathrm{a}$ & $2.40 \mathrm{~b}$ \\
\hline Epace 10 & $1297.6 \mathrm{a}$ & $66.78 \mathrm{a}$ & $12.68 \mathrm{a}$ & $2.72 \mathrm{a}$ \\
\hline CV (\%) & 37.33 & 21.06 & 17.83 & 9.44 \\
\hline
\end{tabular}

${ }^{(1)}$ Means followed by equal letters, in the columns, within each phase, do not differ by the LSD test, at $5 \%$ probability. ${ }^{(2)}$ BSA, bovine albumin serum; and FM, fresh mass.

Table 3. Number of nodules (NN), nodule dry matter (NDM), and root dry matter (RDM) of four cowpea (Vigna unguiculata) cultivars at the pre-flowering stage ${ }^{(1)}$.

\begin{tabular}{llll}
\hline Cultivar & \multicolumn{3}{c}{ Pre flowering } \\
\cline { 2 - 4 } & NN & NDM & RDM \\
\hline BRS Novaera & $182 \mathrm{a}$ & $0.46 \mathrm{a}$ & $2.21 \mathrm{~b}$ \\
BR 17-Gurguéia & $127 \mathrm{a}$ & $0.36 \mathrm{a}$ & $2.04 \mathrm{~b}$ \\
Paulistinha & $174 \mathrm{a}$ & $0.49 \mathrm{a}$ & $4.00 \mathrm{a}$ \\
Epace 10 & $166 \mathrm{a}$ & $0.39 \mathrm{a}$ & $2.41 \mathrm{~b}$ \\
\hline CV $(\%)$ & 27.05 & 29.69 & 29.01 \\
\hline
\end{tabular}

${ }^{(1)}$ Means followed by equal letters, in the columns, do not differ by the LSD test, at $5 \%$ probability. 
roots during late fructification. The mobilization of $\mathrm{N}$ fixed before flowering contributed with $60 \%$ of the fruits' total intake of the nutrient, while the $\mathrm{N}$ fixed after flowering contributed with the remaining $40 \%$ (Peoples et al., 1983).

The obtained results showed a great similarity among cultivars for leaf area, shoot fresh and dry matter, leaf protein content, and root dry matter. Therefore, since only punctual differences were observed, it was not possible to establish a pattern for the response of the cultivars to the environment. However, Sinclair \& Vadez (2012) and Ferreira et al. (2011) found a close correlation between $\mathrm{N}$ storage in the vegetative tissue and crop mass. According to Sinclair \& Vadez (2012), $\mathrm{N}$ can be stored during vegetative development only when there are tissues available to receive the fixed $\mathrm{N}$; therefore, the amount of $\mathrm{N}$ a plant can store in the vegetative tissue before seed growth is crucial to determine the total amounts of fixed N. Ferreira et al. (2011) reported a significant correlation between grain dry matter and the parameters number of nodules, plant dry matter, and $\mathrm{N}$ accumulated by the plants.

Regarding protein content, the two main fractions, globulin and albumin, represented about 84 and 2\% of the total storage proteins, respectively (Table 4). The studied cultivars did not differ as to globulin content. For albumin, two cultivars were contrasting, Paulistinha, with $0.55 \%$, and Epace 10, with $0.66 \%$. According to Sharma \& Krishna (2017), legume grains, in general, predominantly contain $20-35 \%$ albumins and $43-55 \%$ globulins, which, together, account for $63-90 \%$ of the total grain proteins. In the present study, the albumin content was lower than those found by Sharma \& Krishna (2017) and also than the mean of $27.20 \%$ for albumins and $48.76 \%$ for globulins obtained by Tchiagam et al. (2011).

The reduced albumin content observed in the present work is possibly related to the extraction method used. Although albumin is, by definition, water soluble proteins, most studies with cowpea (Odeigah \& Osanyinpeju, 1996; Vasconcelos et al., 2010; Sharma \& Krishna, 2017) used a saline solution to extract a mixture of globulins and albumins, which were subsequently separated by dialysis. In the method used in this study, the globulin fraction was extracted with $0.5 \mathrm{~mol} \mathrm{~L}^{-1} \mathrm{NaCl}$, while the albumin fraction was extracted, in a following step, with distilled water, which, in comparative terms, can cause globulin overestimation and albumin underestimation.

Globulins are nutritionally deficient in cysteine and methionine, whereas albumins are rich in lysine, cysteine, and methionine (Clemente et al., 1998). For this reason, albumins are often considered a better amino acid and balanced group of proteins than globulins (Clemente et al., 1998). Therefore, the albumin content in the grains may be an interesting criterion for the selection of cultivars in breeding programs that aim to increase the nutritional quality of the grain, especially when there is no significant difference in globulin contents, as noted in the present study.

The contents of prolamins and of acid and basic glutelins were also significant. The highest values were found for 'BRS Novaera', with 0.5 for prolamin

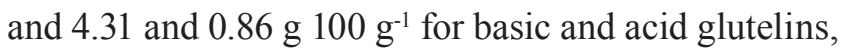
respectively (Table 5). The total soluble protein content ranged from 28.63 to $33.38 \%$ for 'Epace 10 ' and 'Paulistinha', respectively.

Table 4. Storage protein fractions, expressed as percentage of dry flour, in the grains of four cowpea (Vigna unguiculata) cultivars $^{(1)}$.

\begin{tabular}{|c|c|c|c|c|c|c|}
\hline \multirow[t]{2}{*}{ Cultivar } & \multicolumn{5}{|c|}{ Protein fraction $\left({\left.\mathrm{g} 100 \mathrm{~g}^{-1}\right)}^{-1}\right.$} & \multirow{2}{*}{$\begin{array}{c}\text { Total soluble } \\
\text { protein }\end{array}$} \\
\hline & Albumin & Globulin & Prolamin & Basic glutelin & Acid glutelin & \\
\hline BRS Novaera & $0.61 \mathrm{ab}$ & $24.61 \mathrm{a}$ & $0.5 \mathrm{a}$ & $4.31 \mathrm{a}$ & $0.86 \mathrm{a}$ & $30.88 \mathrm{ab}$ \\
\hline BR 17-Gurguéia & $0.63 \mathrm{ab}$ & $26.77 \mathrm{a}$ & $0.35 \mathrm{c}$ & $3.10 \mathrm{c}$ & $0.77 b$ & $31.62 \mathrm{ab}$ \\
\hline Paulistinha & $0.55 \mathrm{~b}$ & $27.88 \mathrm{a}$ & $0.43 b$ & $3.68 \mathrm{~b}$ & $0.84 \mathrm{a}$ & $33.38 \mathrm{a}$ \\
\hline Epace 10 & $0.65 \mathrm{a}$ & $25.21 \mathrm{a}$ & $0.37 b c$ & $1.83 \mathrm{~d}$ & $0.57 \mathrm{c}$ & $28.63 b$ \\
\hline CV (\%) & 10.25 & 10.25 & 9.27 & 6.92 & 6 & 8.7 \\
\hline
\end{tabular}

${ }^{(1)}$ Means followed by equal letters, in the columns, do not differ by the LSD test, at $5 \%$ probability. 
The fractions albumin, prolamin, and basic and acidic glutelins showed significant differences, with contents similar to those reported by Gupta et al. (2010), who found prolamin contents from 0.64 to 1.4 g $100 \mathrm{~g}^{-1}$ and total basic and acid glutelin contents from

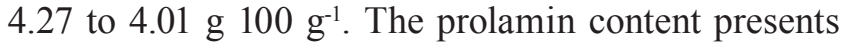
a negative correlation with the lysine content, i.e., cultivars with a high content of prolamins tend to have a low lysine content, which, in nutritional terms, is not good because lysine is a key essential amino acid that, together with threonine, methionine and isoleucine, is derived from the aspartic acid metabolic pathway (Azevedo et al., 2006; Gupta et al., 2010).

The protein band profiles of all four cultivars varied in number, width, and intensity (Figure 1). The relative molecular mass ranged between 10 and $90 \mathrm{kDa}$ for the albumin fraction, 15 and $100 \mathrm{kDa}$ for globulins, 15 and $90 \mathrm{kDa}$ for prolamins, and 15 and $100 \mathrm{kDa}$ for acid and basic glutelins. BRS Novaera exhibited different band patterns for albumins, globulins, and basic glutelins, compared with the other cultivars. It also presented one polypeptide between 10 and $15 \mathrm{kDa}$ for albumin, a lower intensity band between 20 and $25 \mathrm{kDa}$ for the globulin fraction, and the suppression or non-detection of the band of $40 \mathrm{kDa}$ for acid glutelin. For the BR 17-Gurguéia cultivar, the prolamin bands between 50 and $70 \mathrm{kDa}$ were absent or not detected.

The polymorphism shown by the BRS Novaera and BR 17-Gurguéia cultivars can be better exploited in assisted selection studies or in studies that seek to identify allergy-causing proteins in legumes, since several classes of storage proteins have been associated with these types of allergies. Most of the bands were common in all cultivars, which indicates a close relationship among them (Figure 1). Gupta et al. (2014) found bands ranging from 15.85 to $147.9,10$ to 125.9 , 7.94 to 56.23 , and 10 to $79.43 \mathrm{kDa}$ for the albumin, globulin, prolamin, and glutelin contents, respectively, of 11 cowpea genotypes (CS88, Chirrodi, HC98-64, HC6, LST-IIC12, CP16, CP21, COVU702, HC5, V240, and FS68).

Only seven amino acids (histidine, arginine, cysteine, lysine, tyrosine, methionine, and phenylalanine) differed significantly among cultivars

Table 5. Soluble amino acid content in the grains of four cowpea (Vigna unguiculata) cultivars ${ }^{(1)}$.

\begin{tabular}{|c|c|c|c|c|c|}
\hline \multirow{2}{*}{$\begin{array}{l}\text { Soluble } \\
\text { amino acid }\end{array}$} & \multicolumn{4}{|c|}{ Cultivar } & \multirow{2}{*}{$\begin{array}{l}\text { CV } \\
(\%)\end{array}$} \\
\hline & BRS Novaera & BR 17-Gurguéia & Paulistinha & Epace 10 & \\
\hline & \multicolumn{5}{|c|}{ Essential ( $\mu \mathrm{g}$ amino acid per $100 \mathrm{~g}$ dry flour) } \\
\hline Histidine & $0.422 b$ & $0.729 \mathrm{ab}$ & $0.995 \mathrm{a}$ & $0.813 \mathrm{ab}$ & 25.06 \\
\hline Threonine & $0.118 b$ & $0.107 \mathrm{~b}$ & $0.105 b$ & $0.105 b$ & 15.47 \\
\hline Lysine & $0.048 \mathrm{a}$ & $0.045 \mathrm{ab}$ & $0.047 \mathrm{a}$ & $0.041 \mathrm{~b}$ & 28.44 \\
\hline Methionine & $0.029 \mathrm{a}$ & $0.025 \mathrm{ab}$ & $0.024 \mathrm{~b}$ & $0.023 b$ & 24.28 \\
\hline Phenylalanine & $0.440 \mathrm{~b}$ & $0.386 \mathrm{~b}$ & $0.495 b$ & $0.916 \mathrm{a}$ & 5.11 \\
\hline Isoleucine & $0.053 b$ & $0.053 b$ & $0.061 \mathrm{~b}$ & $0.058 \mathrm{~b}$ & 10.31 \\
\hline \multirow[t]{2}{*}{ Leucine } & $0.047 \mathrm{~b}$ & $0.037 \mathrm{~b}$ & $0.044 b$ & $0.047 \mathrm{~b}$ & 8.64 \\
\hline & \multicolumn{5}{|c|}{ Nonessential ( $\mu \mathrm{g}$ amino acid per $100 \mathrm{~g}$ dry flour) } \\
\hline Arginine & $0.599 \mathrm{bc}$ & $0.308 \mathrm{c}$ & $1.768 \mathrm{a}$ & $0.804 \mathrm{~b}$ & 14.68 \\
\hline Aspartate & $0.245 \mathrm{a}$ & $0.410 \mathrm{a}$ & $0.468 \mathrm{a}$ & $0.366 \mathrm{a}$ & 19.27 \\
\hline Serine & $0.092 \mathrm{a}$ & $0.089 \mathrm{a}$ & $0.198 \mathrm{a}$ & $0.151 \mathrm{a}$ & 17.65 \\
\hline Alanine & $0.206 \mathrm{a}$ & $0.192 \mathrm{a}$ & $0.199 \mathrm{a}$ & $0.147 \mathrm{a}$ & 17.54 \\
\hline Cysteine & $0.020 \mathrm{a}$ & $0.013 b$ & $0.014 \mathrm{~b}$ & $0.014 \mathrm{~b}$ & 33.7 \\
\hline Tyrosine & $0.206 \mathrm{~b}$ & $0.083 \mathrm{c}$ & $0.217 \mathrm{ab}$ & $0.256 \mathrm{a}$ & 25.91 \\
\hline Valine & $0.127 \mathrm{a}$ & $0.131 \mathrm{a}$ & $0.182 \mathrm{a}$ & $0.182 \mathrm{a}$ & 24.6 \\
\hline Proline & $0.238 \mathrm{a}$ & $0.228 \mathrm{a}$ & $0.308 \mathrm{a}$ & $0.171 \mathrm{a}$ & 24.56 \\
\hline Glycine & $0.107 \mathrm{a}$ & $0.084 \mathrm{a}$ & $0.102 \mathrm{a}$ & $0.083 \mathrm{a}$ & 27.33 \\
\hline
\end{tabular}

${ }^{(1)}$ Means followed by equal letters, in the columns, do not differ by the LSD test, at 5\% probability. 
A $\mathrm{kDa}$

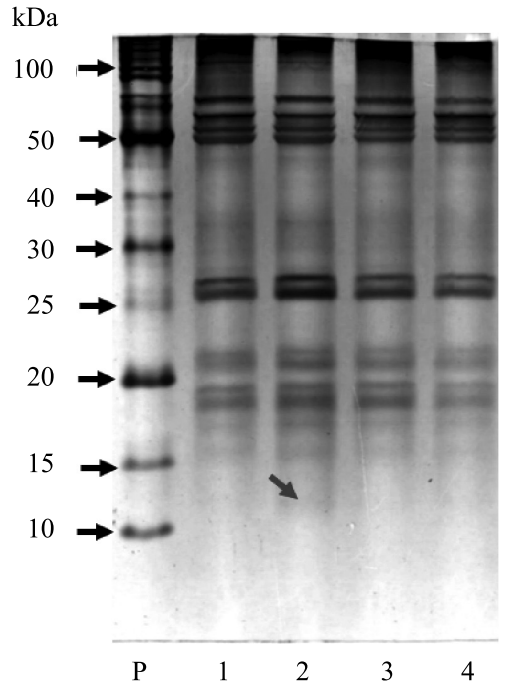

B

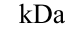

$\mathrm{kDa}$

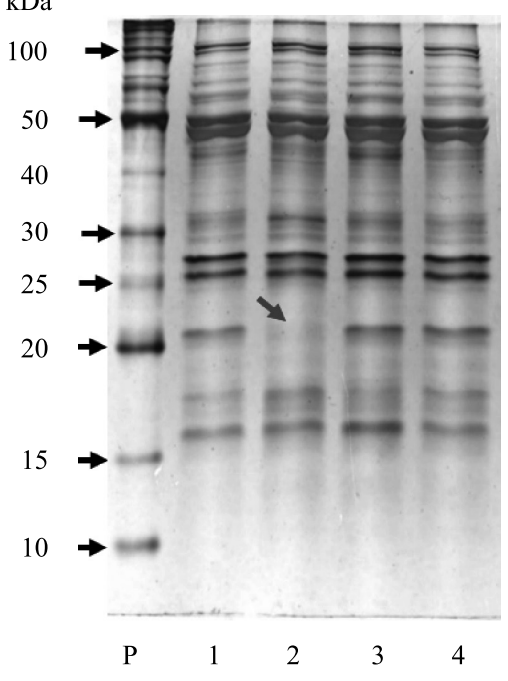

C $\mathrm{kDa}$

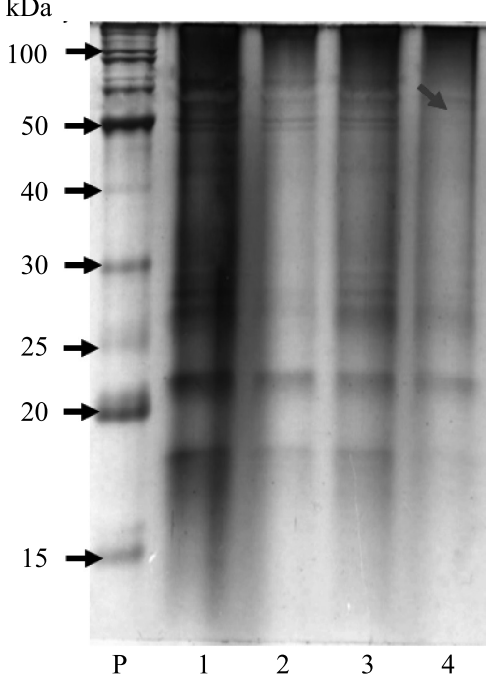

$\mathrm{D} \quad \mathrm{kDa}$

E $\quad \mathrm{kDa}$
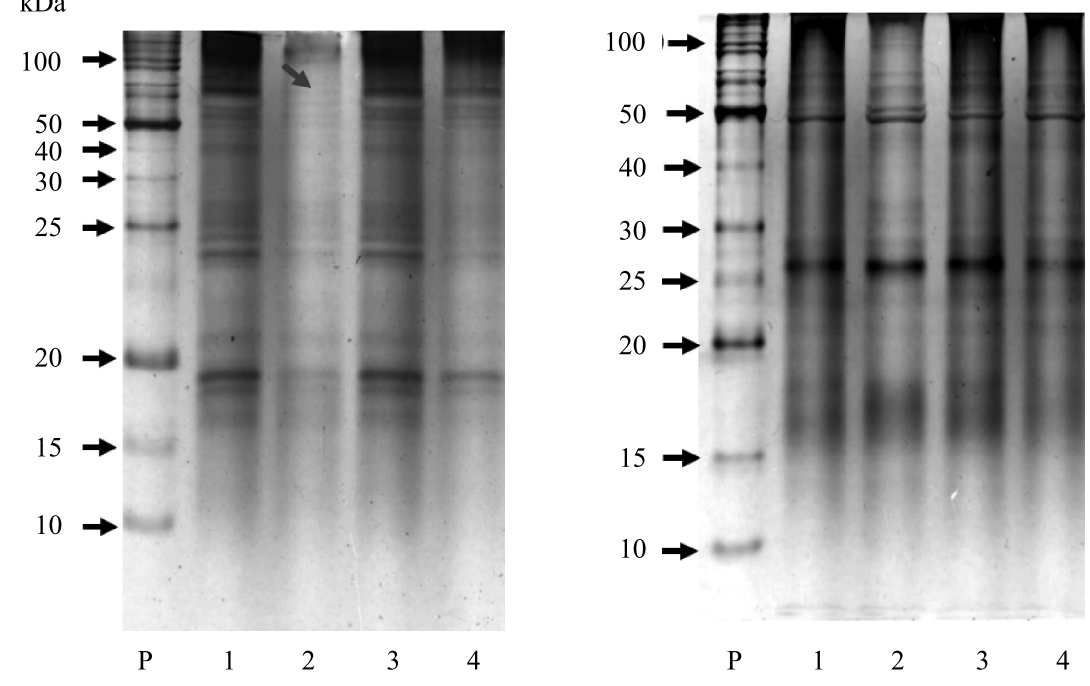

Figure 1. SDS-1D electrophoretic profile of cowpea (Vigna unguiculata) cultivars, for: A, albumins; B, globulins; C, prolamins; D, acid glutelin; and E, basic glutelin. Lanes: P, molecular mass standard; 1, Paulistinha cultivar; 2, BRS Novaera cultivar; 3, Epace 10 cultivar; and 4, BR 17-Gurguéia cultivar. The arrows indicate band positions: A, presence of an extra band; $\mathrm{B}$, lower band intensity; and $\mathrm{C}$ and $\mathrm{D}$, band suppression.

(Table 5). BRS Novaera showed the highest contents of sulfur amino acids (methionine + cysteine -0.049 $\mu \mathrm{g} 100 \mathrm{~g}^{-1}$ ) and did not differ from the other cultivars as to globulin content. This result differs from that of Gupta et al. (2010), who found a negative correlation of both globulins and sulfur amino acids (methionine and cysteine) with prolamins and lysine. In the present study, there was no correlation between prolamin and lysine contents, since both 'Paulistinha', with more prolamin, and 'BR 17-Gurguéia', with less prolamin, did not differ as to lysine.

\section{Conclusions}

1. The BRS Novaera and BR 17-Gurguéia cowpea (Vigna unguiculata) cultivars have the highest content 
of soluble sulfur amino acids and methionine in their grains, with the presence of polymorphic bands, which makes them an important genetic material for breeding programs, aiming to improve the nutritional quality of the species.

2. Protein quantity and quality variables in the grain differ greatly between cultivars, showing a greater applicability in selection programs.

\section{Acknowledgments}

To Fundação de Amparo à Pesquisa do Estado de São Paulo (Fapesp), for grant (number 2012/500978); and to Conselho Nacional de Desenvolvimento Científico e Tecnológico (CNPq), for scholarship.

\section{References}

AZEVEDO, R.A.; LANCIEN, M.; LEA, P.J. The aspartic acid metabolic pathway, an exciting and essential pathway in plants. Amino Acids, v.30, p.143-162, 2006. DOI: https://doi.org/10.1007/ s00726-005-0245-2.

BIELESKI, R.L.; TURNER, N.A. Separation and estimation of amino acids in crude plant extracts by thin-layer electrophoresis and chromatography. Analytical Biochemistry, v.17, p.278-293, 1966. DOI: https://doi.org/10.1016/0003-2697(66)90206-5.

BRADFORD, M.M. A rapid and sensitive method for the quantitation of microgram quantities of protein utilizing the principle of protein-dye binding. Analytical Biochemistry, v.72, p.248-254, 1976. DOI: https://doi.org/10.1016/00032697(76)90527-3.

CLEMENTE, A.; SÁNCHEZ-VIOQUE, R.; VIOQUE, J.; BAUTISTA, J.; MILLÁN, F. Effect of cooking on protein quality of chickpea (Cicer arietinum) seeds. Food Chemistry, v.62, p.1-6, 1998. DOI: https://doi.org/10.1016/S0308-8146(97)00180-5.

ELHARDALLOU, S.B.; KHALID, I.I.; GOBOURI, A.A.; ABDEL-HAFEZ, S.H. Amino acid composition of cowpea (Vigna ungiculata L. Walp) flour and its protein isolates. Food and Nutrition Sciences, v.6, p.790-797, 2015. DOI: https://doi.org/10.4236/fns.2015.69082.

FERREIRA, E.P. de B.; MARTINS, L.M.V.; XAVIER, G.R.; RUMJANEK, N.G. Nodulação e produção de grãos em feijãocaupi (Vigna unguiculata L. Walp.) inoculado com isolados de rizóbio. Revista Caatinga, v.24, p.27-35, 2011.

FREIRE, L.R. (Coord.). Manual de calagem e adubação do Estado do Rio de Janeiro. Brasília: Embrapa; Seropédica: Ed. Universidade Rural, 2013.

GERRANO, A.S.; VAN RENSBURG, W.S.J.; VENTER, S.L.; SHARGIE, N.G.; AMELEWORK, B.A.; SHIMELIS, H.A.; LABUSCHAGNE, M.T. Selection of cowpea genotypes based on grain mineral and total protein content. Acta Agriculturae
Scandinavica, Section B - Soil \& Plant Science, v.69, p.155-166, 2019. DOI: https://doi.org/10.1080/09064710.2018.1520290.

GUPTA, P.; SINGH, R.; MALHOTRA, S.; BOORA, K.S.; SINGAL, H.R. Characterization of seed storage proteins in high protein genotypes of cowpea [Vigna unguiculata (L.) Walp.]. Physiology and Molecular Biology of Plants, v.16, p.53-58, 2010. DOI: https://doi.org/10.1007/s12298-010-0007-9.

GUPTA, P.; SINGH, R.; MALHOTRA, S.; BOORA, K.S.; SINGAL, H.R. Cowpea [Vigna unguiculata (L.) walp.] seed proteins: heterogeneity in total proteins and protein fractions. Legume Research: an International Journal, v.37, p.62-67, 2014. DOI: https://doi.org/10.5958/j.0976-0571.37.1.009.

HUNGRIA, M.; CAMPO, R.J.; MENDES, I.C. Benefits of inoculation of the common bean (Phaseolus vulgaris) crop with efficient and competitive Rhizobium tropici strains. Biology and Fertility of Soils, v.39, p.88-93, 2003. DOI: https://doi.org/10.1007/s00374-003-0682-6.

LOWRY, O.H.; ROSEBROUGH, N.J.; FARR, A.L.; RANDALL, R.J. Protein measurement with the Folin phenol reagent. Journal of Biological Chemistry, v.193, 265-275, 1951.

MASCLAUX-DAUBRESSE， C.; REISDORF-CREN， M.; ORSEL, M. Leaf nitrogen remobilisation for plant development and grain filling. Plant Biology, v.10, p.23-36, 2008. Supplement 1. DOI: https://doi.org/10.1111/j.1438-8677.2008.00097.x.

MORRISSEY, J.H. Silver stain for proteins in polyacrylamide gels: a modified procedure with enhanced uniform sensitivity. Analytical Biochemistry, v.117, p.307-310, 1981. DOI: https://doi.org/10.1016/0003-2697(81)90783-1.

ODEIGAH， P.G.C.; OSANYINPEJU, A.O. Seed protein electrophoretic characterization of cowpea (Vigna unguiculata) germplasm from IITA gene bank. Genetic Resources and Crop Evolution, v.43, p.485-491, 1996. DOI: https://doi.org/10.1007/ BF00138825.

PEOPLES, M.B.; PATE, J.S.; ATKINS, C.A. Mobilization of nitrogen in fruiting plants of a cultivar of cowpea. Journal of Experimental Botany, v.34, p.563-578, 1983. DOI: https://doi.org/10.1093/jxb/34.5.563.

RAVELOMBOLA, W.S.; SHI, A.; WENG, Y.; MOTES, D.; CHEN, P.; SRIVASTAVA, V.; WINGFIELD, C. Evaluation of total seed protein content in eleven Arkansas cowpea (Vigna unguiculata (L.) Walp.) lines. American Journal of Plant Sciences, v.7, p.2288-2296, 2016. DOI: https://doi.org/10.4236/ ajps.2016.715201

SANTOS, M.A.; GERALDI, I.O.; GARCIA, A.A.F.; BORTOLATTO, N.; SCHIAVON, A.; HUNGRIA, M. Mapping of QTLs associated with biological nitrogen fixation traits in soybean. Hereditas, v.150, p.17-25, 2013. DOI: https://doi.org/10.1111/j.1601-5223.2013.02275.x.

SHARMA, D.B.; KRISHNA, K.R. Genetic diversity in cowpea [Vigna unguiculata (L.) Walp.] accessions using protein profiling. International Journal of Pure \& Applied Bioscience, v.5, p.491496, 2017. DOI: https://doi.org/10.18782/2320-7051.2768.

SILVA, M. de F. da; SANTOS, C.E. de R. e S.; SOUSA, C.A. de; ARAÚJO, R. de S.L.; STAMFORD, N.P.; FIGUEIREDO, M. 
do V.B. Nodulação e eficiência da fixação do $\mathrm{N}_{2}$ em feijão-caupi por efeito da taxa do inóculo. Revista Brasileira de Ciência do Solo, v.36, p.1418-1425, 2012. DOI: https://doi.org/10.1590/S010006832012000500005 .

SINCLAIR, T.R.; VADEZ, V. The future of grain legumes in cropping systems. Crop and Pasture Science, v.63, p.501-512, 2012. DOI: https://doi.org/10.1071/CP12128.

SINGH, R.J.; CHUNG, G.H.; NELSON, R.L. Landmark research in legumes. Genome, v.50, p.525-537, 2007. DOI: https://doi.org/10.1139/G07-037.
TCHIAGAM, J.-B.N.; BELL, J.M.; NASSOUROU, A.M.; NJINTANG, N.Y.; YOUMBI, E. Genetic analysis of seed proteins contents in cowpea (Vigna unguiculata L. Walp.). African Journal of Biotechnology, v.10, p.3077-3086, 2011. DOI: https://doi.org/10.5897/AJB10.2469.

VASCONCELOS, I.M.; MAIA, F.M.M.; FARIAS, D.F.; CAMPELLO, C.C.; CARVALHO, A.F.U.; AZEVEDO MOREIRA, R. de; OLIVEIRA, J.T.A. de. Protein fractions, amino acid composition and antinutritional constituents of highyielding cowpea cultivars. Journal of Food Composition and Analysis, v.23, p.54-60, 2010. DOI: https://doi.org/10.1016/j. jfca.2009.05.008. 